\title{
Rare plant species of salt marshes of the Croatian coast
}

\section{Daniel Dítě , Zuzana Dítětová1, Pavol Eliáš jun. ${ }^{2}$ \& Róbert Šuvada ${ }^{3}$}

Keywords: halophytes, distribution, rare species, Eastern Adriatic Sea.

Ključne besede: halofiti, razširjenost, redke vrste, vzhodni Jadran.

Received: 14.03 .2017

Revision received: 28. 01. 2018

Accepted: 30. 01. 2018

\begin{abstract}
Between 2011 and 2016 we surveyed 42 sites of coastal salt marshes of Croatia. We confirmed the occurrence of several rare and endangered plant species. Ten of them are included in the Red List of Croatia; critically endangered (CR) Eleocharis uniglumis, Triglochin barrelieri and T. maritima, endangered (EN) Carex divisa and C. extensa, vulnerable (VU) Parapholis incurva, Salsola soda and Suaeda maritima and category data deficient (DD) Limonium virgatum and Puccinellia festuciformis. We also report localities of other rare taxa of salt marshes like Allium telmatum, Tripolium pannonicum subsp. tripolium, Juncus gerardii, Parapholis filiformis, Plantago cornuti, Samolus valerandi and Scorzonera parviflora. Several plant species are endangered. Their habitats, salt marshes were converted into fields or destructed by construction for developing tourist infrastructure. Today only a part of the remained areas are under protection.

\section{Izvleček}

Med letoma 2011 in 2016 smo pregledali 42 lokalitet obalnih slanih močvirij na Hrvaškem. Potrdili smo pojavljanje številnih redkih in ogroženih rastlinskih vrst. Deset jih je vključenih na rdeči seznam Hrvaške; skrajno ogrožene (CR) Eleocharis uniglumis, Triglochin barrelieri in T. maritime, ogrožene (EN) Carex divisa in C. extensa, ranljive vrste Parapholis incurva, Salsola soda in Suaeda maritime, ter iz kategorije premalo znane vrste (DD) Limonium virgatum in Puccinellia festuciformis. Poročamo tudi o nahajliščih drugih redkih vrst na slanih močvirjih kot so Allium telmatum, Tripolium pannonicum subsp. tripolium, Juncus gerardii, Parapholis filiformis, Plantago cornuti, Samolus valerandi in Scorzonera parviflora. Številne rastlinske vrste so ogrožene. Njihova rastišča so spremenili v njive ali pa so jih uničili z gradnjo turistične infrastrukture. Danes je le del teh preostalih območij zaščiten.
\end{abstract}

1 Institute of Botany, Plant Science and Biodiversity Centre, Slovak Academy of Sciences, Dúbravská cesta 9, SK-845 23, Bratislava, Slovakia. E-mail: daniel.dite@savba.sk, zuzana.dite@savba.sk

2 Department of Botany, Slovak University of Agriculture, Tr. A. Hlinku 2, SK-949 76 Nitra, Slovakia. E-mail: pavol.elias.jun@gmail.com

3 Administration of the Slovenský kras National Park, Hámosiho 188, SK-049 51 Brzotín, Slovakia. E-mail: robert.suvada@sopsr.sk 


\section{Introduction}

Natural sea coasts are very diverse and also highly threatened habitats throughout Europe (Cori 1999, Kutiel et al. 2000, EEA 2006) by industrial activities, traffic, tourism, drainage, land use changes, abandonment from traditional farming, eutrophication (salt meadows and marshes) and pollution (EEA 2006). This wholeEuropean trend is observed also on the Adriatic coast with a highly developed tourist infrastructure. Rocky, indented coastlines which in Croatia prevail are today subjected to massive construction of resorts and marinas. Flat shores occur mostly in broad river estuaries. In Croatia the low flat coastline is naturally rare, therefore are more threatened due to their easier accessibility. Such places were usually inhabited earlier and they were used as salt works (Solanas) (e.g. Ston, Nin, Pag). These shallow ponds for salt production provided secondary habitats for salt marsh vegetation. Several salt marshes were converted into intensive agricultural fields (e.g. Neretva River Delta) and those which have remained undrained were utilized as pastures (Stančić et al. 2008). Today only a few areas are under protection. Nature reserves were declared, for instance in the estuary of the Karišnica River (Karin Gornji), in Ninsko blato and on the island of Pag Malo Blato and Kolansko blato. The Neretva River Delta, listed in the Ramsar Convention, is under the process of establishing a protected area for its proper management (Glasnović et al. 2007).

We provide brief description about the recently confirmed localities, vegetation characteristics and population size of the following rare native plant species occurring on coastal saline wetlands of Croatia: Allium telmatum, Tripolium pannonicum subsp. tripolium, Carex divisa, C. extensa, Eleocharis uniglumis, Juncus gerardii, Limonium virgatum, Parapholis filiformis, P. incurva, Plantago cornuti, Salsola soda, Samolus valerandi, Scorzonera parviflora, Suaeda maritima, Triglochin barrelieri and T. maritima. From these species $C$. divisa, C. extensa, E. uniglumis, J. gerardii, P. cornuti, S. soda, S. valerandi, S. parviflora and T. maritima grow in inland saline habitats as well (Eliáš et. al 2013, Király et al. 2013).

This survey is not objected to detailed analysis of coastal vegetation. Our aim was to summarize our findings on the recent occurrence of rare species in the context of the regional and local literature available and to contribute towards a more comprehensive knowledge of the vascular flora of the study area. We also give short information about the interesting areas of salt marshes on the Croatian coastline.

\section{Material and methods}

We considered the target habitat according to definition of Adam (1990): salt marshes or tidal marshes are a coastal ecosystem in the upper coastal intertidal zone between land and open salt water or brackish water that is regularly flooded by the tides.

\section{Study area}

The study was carried out in the area of the Central and North East Adriatic. The southernmost location was the site near Ston ( $\left.42^{\circ} 49^{\prime} 40.1^{\prime \prime}, 17^{\circ} 42^{\prime} 4.2^{\prime \prime}\right)$, the northernmost one was the Mirna River mouth on the Istrian peninsula $\left(45^{\circ} 19^{\prime} 11.9^{\prime \prime}, 13^{\circ} 36^{\prime} 3.5^{\prime \prime}\right.$, Figure 1).

According to its geological structure, the east coast of the Adriatic shows predominance of limestone and dolomites from the cretaceous period, forming, for the most part, a low-lying and rocky coast, while the areas of low and alluvial marshy coasts are very rare (cf. Pandža et al. 2007).

\section{Data collection}

Dates of individual visits are given at particular locations. The sites were found (Figure 1) according to the available literature data and with the help of the program Google Earth. Particular attention was paid to plant species linked to coastal salt marshes included in the Red Book of Croatia (Nikolić \& Topić 2005) and Flora Croatica (Nikolić 2017). Other salt marsh species were selected according to Stančić et al. (2008). Species of other coastal habitats (sand dunes, rock cliffs) were not subjected to this survey. Plant nomenclature follows Euro+Med (2017). We classified the vegetation on alliance level followed by the works of Pandža et al. (2007) and Stančić et al. (2008), names of syntaxa follow Mucina et al. (2016). The list of all surveyed sites with short descriptions is given in the Appendix.

\section{Results}

42 sites of salt marshes were visited of the Croatian coastline between years 2011-2016. The most common species typical to the examined habitat were Halimione portulacoides, Juncus maritimus, Limonium narbonense, Puccinellia festuciformis and Sarcocornia fruticosa (for particular locations see the List of sites). We confirmed the occurrence of several rare and endangered plant species of the Croatian Red List. In category critically endangered (CR) we found Eleocharis uniglumis, Triglochin barrelieri and T. maritima, in category endangered (EN) 

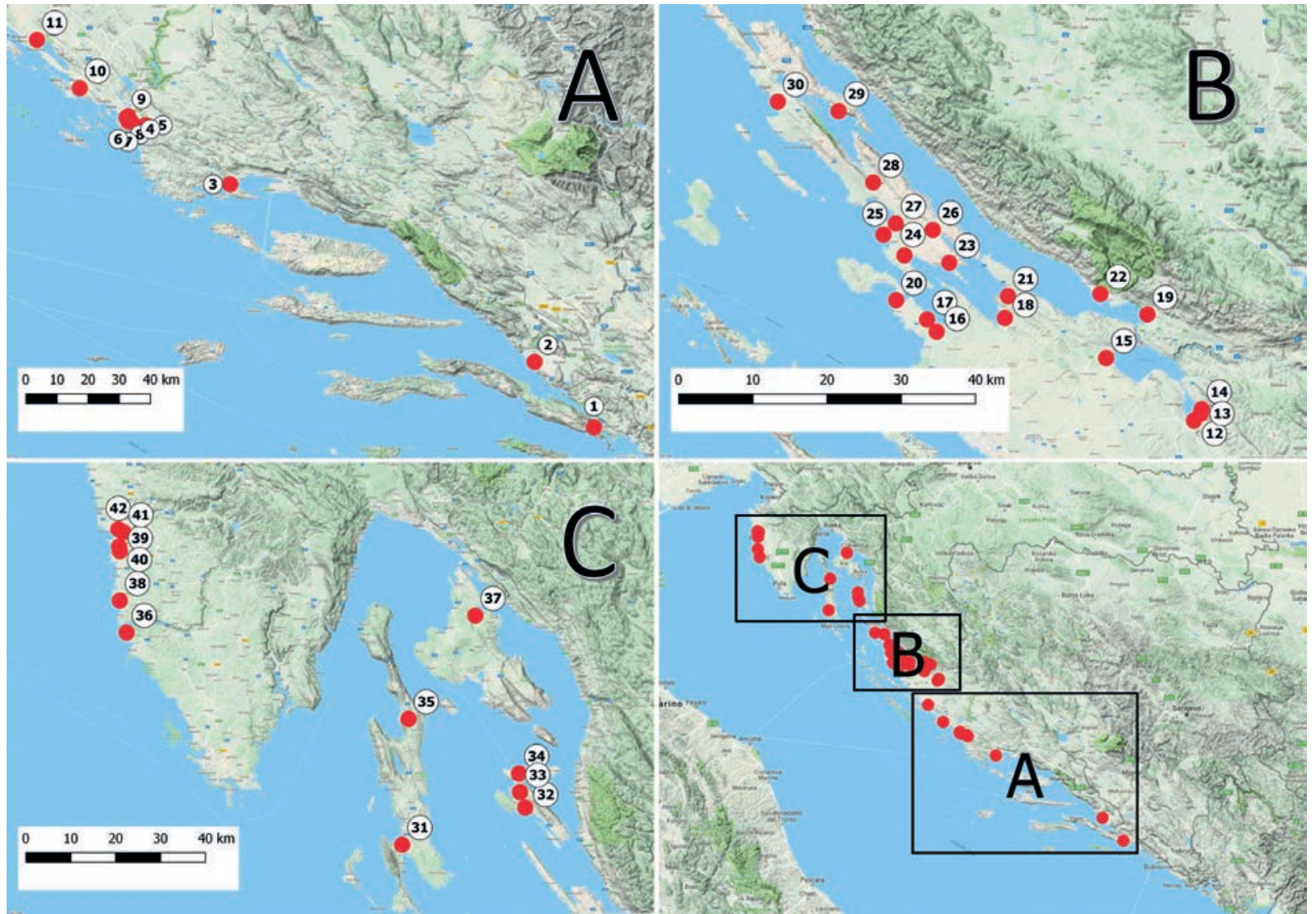

Figure 1: Map of the studied area (See the list of localities and their short description in Appendix 1).

Slika 1: Zemljevid preučevanega območja (seznam lokalitet in njihov kratek opis je v Prilogi 1).

Carex divisa and C. extensa, in category vulnerable (VU) Parapholis incurva, Salsola soda and Suaeda maritima and in category data deficient (DD) Limonium virgatum and Puccinellia festuciformis. In addition, P. festuciformis was recorded on each site.

\section{Critically endangered species (CR)}

Eleocharis uniglumis: this rare species was found on 6 sites. Each of them is located on the island of Pag and its vicinity. It grew in the upper salt marshes, away from the tidal zone in the vegetation of the alliance Juncion maritimi on less saline soils.

Triglochin barrelieri: rare species, obliged strictly to coastal salt marshes. We confirmed it on 7 locations. In Zablaće near Šibenik was recorded on two sites in the vegetation of the alliance Salicornion fruticosae. Small population was found on the northern part of Ninsko blato. On other two neighboring sites (Rtina and Ljubač), richer populations were found with thousands of individuals. It was recorded most frequently in the vegetation of the alliance Juncion maritimi. In Ljubač the species created also initial stands on the sandy beach. Smaller populations were found in the vegetation of the alliance Salicornion fruticosae in Privlaka south of the island of Vir. The northernmost stands were observed in Vlašiči on the island of Pag where it grew in vegetation of both above mentioned alliances.

Triglochin maritima: only three sites were confirmed. Rich population was found in Ninsko blato in the alliance Juncion maritimi. Two sites close to each other were found on the Istrian peninsula: several specimens were recorded in a small fragment of salt marsh near Lanterna (site no. 41) and rich stands were found in the Mirna River estuary. The species grew in flooded, initial species-poor vegetation together with Juncus maritimus, Limonium narbonense and Puccinellia festuciformis.

\section{Endangered species (EN)}

Carex divisa: a relatively widely-distributed species which was confirmed on 14 sites. It created dense stands on margins of salt marshes within the alliance Juncion maritimi with a transition to humid grasslands of the alliance Molinio-Hordeion secalini. Rich populations were found in Jadrtovac, Rtina, Ninska solana and 
on several sites on the island of Pag (Vlašići, Povljana, Paška solana, Kolansko blato). The species combination with pure stands of Sarcocornia fruticosa is interesting from coenological point of view. We found it in Supetarska Draga on the island of Rab.

Carex extensa: one of the common species not only of salt marshes. It was found on 23 locations, while populations were usually poor. Its coenological optimum was found in stands of the alliance Salicornion fruticosae and less frequently in Juncion maritimi. Carex extensa occurred outside salt marshes as well, especially on rock coast affected by seawater, for instance in Supetar, Sumartin (island Brač in yrs 2010 and 2011) and Rukavac (island Vis in 2013).

\section{Vulnerable species (VU)}

Suaeda maritima: this species obliged to salt marshes was recorded relatively rarely, on 12 sites. It grew most frequently in initial stands of the alliances Therosalicornion and Salicornion fruticosae on wet soils with the highest salt content [Zablaće, Vrulje, Brodarica, Privlaka; Supetarska Draga and Lopar (island Rab); and several sites in Istria] or in salt works (Ninska solana, Paška solana). In the highly attacked Pantan reserve near Trogir (Kamenjarin \& Pavletić 2002, Vladović et al. 2015) it was not confirmed. Occassionally it was found outside of mud flat salt marshes, in the Neretva River Delta near Blace on gravel coasts.

Parapholis incurva: we detected the species only on four sites of salt marshes. It grew in species-rich stands of the alliance Salicornion fruticosae in Zablaće - Malo jezero, Privlaka, Rtina and Ljubač. More often was recorded in initial gravel habitats.

Salsola soda: the species was found on five sites in open, relatively-species rich vegetation of the alliances Salicornion fruticosae and Juncion maritimi on several micro-sites in Zablaće (together with Pharapholis incurva), in the vegetation of the alliance Salicornion fruticoase in Posedarje and Vlačiši. In Pantan reserve near Trogir where Kamenjarin \& Pavletić (2002) report association Salsoletum sodae, it was not confirmed. Similarly as $P$. incurva, $S$. soda was more frequent outside of salt marshes, e.g. on gravel beaches (Supetar on the island Brač, several places on Pag and Vir islands). These two species according to our observations do not avoid disturbed, semi-natural coastal habitats.

\section{Data deficient (DD)}

Limonium virgatum: this rare species was confirmed in Zablaće-Malo jezero (Mala Solina), Privlaka and Ljubač in species rich vegetation of the alliance Salicornion fruticosae.

\section{Rare species not included in the Red List:}

Allium telmatum was found on several locations on Pag Island in the vegetation of Salicornion fruticosae (Dinjiško polje, Paška Solana) and Juncion maritimi as well (Vlašići, Malo blato, Kolansko blato, Metjana and Ninsko blato).

Tripolium pannonicum subsp. tripolium: relatively frequent species of salt marshes. We found it on 17 sites mostly in Juncion maritimi communities: Rtina, Ljubač, Vlašići, Povljana, Paška solana, Modrić, Blace or in more initial stages of the same vegetation (Zablaće, Posedarje, Paška solana). In Vrulje, Karin Gornji, Kampor (Rab Island), Soline (Krk Island) and Funtana (Istria) we recorded the species in the alliance Salicornion fruticosae.

Juncus geradii is similarly frequent, confirmed on 16 sites

(Figure 1): Rtina, Vlašići, Povljana and Paška solana as a component of the alliance Juncion maritimi. Smaller populations were found within the alliance Salicornion fruticosae - Vrulje, Soline (Krk), Osor (Cres) and Lanterna (Istria). In Ivinj, Ljubač, Modrić, Zablaće or Soline (Krk) it often created pure mono-dominant stands on the margins of salt marshes.

Parapholis filiformis: the species occurred very rarely in salt-marsh vegetation, only on two new sites (Pag, Vlašici and Rtina) in species-rich stands of the alliance Salicornion fruticosae in small populations.

Plantago cornuti: this species was found rarely, in four sites (Ninsko blato, Ninska solana, Ljubač, Povljana) always in the stands of Juncion maritimi.

Samolus valerandi: in salt marshes the species was recorded relatively rarely, on 9 sites, in the vegetation of the alliance Juncion maritimi. In the northern part of Vransko jezero it created pure initial stands or it grew together with Juncus maritimus and Schoenoplectus litoralis on exposed rocky banks.

Scorzonera parviflora: the species was recorded on 11 sites, 6 of them were located on Pag. It occurred strictly in stands of Juncion maritimi; in Vlašići it was found rarely in transition vegetation between this alliance and Salicornion fruticosae. Several sites are featured with large stands with very rich populations of the species (thousands of individuals), e.g. Ljubač, Rtina, Vlašići or Kolansko blato.

On many localities were recorded Salicornia europea agg. Since most of the sites were visited in the first half of the vegetation season (end of April - beginning of May) when specimens were immature, we determined it only on aggregate level. The most typical stands were developed in the mouth of Karišinica River (Karin Gornji) where it created large mud flat zones in the vegetation of Therosalicornion. 


\section{Discussion}

From 129 plant species growing on the Croatian coasts 41 are obliged to coastal salt marshes (Stančić et al. 2008). Less than the half of them (16) is included in the Croatian Red Book (Nikolić \& Topić 2005). Four species are listed in the highest threat category (CR): Triglochin barrelieri, T. maritima, Pancratium maritimum and Puccinellia distans subsp. distans. The latter one is expanding along roadsides of Western and Central Europe in the last decades (Šerá 2008, Brandes 2009, Dítě \& Dítětová 2016).

Triglochin barrelieri has according to Stančić et al. (2008) three localities on the coastline, mostly in the vegetation of the alliance Salicornion fruticosae. Nikolić \& Topić (2005) and Mitić et al. (2009) reported the species from two sites on Pag Island (Dinjiško polje, Vlašići), where it was published also by Horvatić (1934). It is recorded in the same vegetation by Nikolić \& Topić (l. c.) from Krapanj (also Pandža 1998), Zablaće and the vicinity of Šibenik (e.g. Milović 2002). Alegro et al. (2010) reports it from three Important Plant Areas (IPA): Otok Pag, Šibenski arhipelag (otok Murter) and Rtina-Miočići. From Murter Island it is reported by Milović \& Pandža (2010). Sites Privlaka and Ljubač were not published so far.

The richest populations were observed in the alliance Juncion maritimi and on sandy beaches in pioneer vegetation flooded by seawater.

According to Stančić et al. (2008) Triglochin maritima has occupy 6 localities in stands of Salicornion fruticosae. Except the northern part of the Istrian peninsula (Nikolic $\&$ Topić 2005, Rottensteiner 2012) the species was found also in Ninsko blato in the vegetation of Juncion maritimi which was not known in the literature.

Eleocharis uniglumis according to the Red Book of Croatia has 7 localities: only two of them on the coast, Mljet Island (Mitić et al. 2009) and Pula (Nikolić \& Topić 2005). Rottensteiner (2012) mentioned it from coastline near Poreć. Sites found by us were not published so far. The richest populations were found in Povljana (Pag) and in brackish marshes of Vransko jazero.

Although Carex divisa and C. extensa have high threat category in the Red List (EN) they appear to be common species in the study area. According to Stančić et al. (2008) C. extensa was found at 106 locations. The high number of sites is related to the ecological requirements of the species. Several sites (Ljubač, Rtina, Nin, Privlaka) where the species was found during our survey are not included in the Red Book, even the sites on Brač and Vis islands. Species of category VU appear to be common as well. For instance Parapholis incurva has according to Stančić et al. (2008) 100 known locations in several vegetation types, even in ruderal habitats, Suaeda maritima has 92 and Salsola soda 75 locations (Stančić et al. l. c., Nikolić 2017). Both last two above mentioned species are regarded relatively common also in other works (e.g. Starmühler 2003, 2007, Mitić et al. 2009, Rottensteiner 2014a).

Conversely, numerous rare species of the Croatian coast are not included in the Red Book. For example Parapholis filiformis has occurred, according to Stančić et al. (2008), only at single locality in Croatia. Subsequently, the species was published in the inventory of the flora of Vis (Mitić et al. 2009) and it is reported also from Brač in the actual national database of the Croatian flora (Nikolić 2017). The above mentioned data show that $P$. filiformis is a very rare species. Our two confirmed localities (Rtina and Vlašići) are new to Croatia. The plant grows there in species-rich stands of the alliance Salicornion fruticosae.

Distribution of Plantago cornuti in Croatia is insufficiently known. Stančić et al. (2008) reports only a single location. Further locations mentioned Mitić at al. (2008) and Nikolić (2017) on the islands of Cres and Lošinj (S Istria), near Obrovac, in Krka National Park and Split (central aj S Dalmatia). Our localities are concentrated in relatively limited area in N Dalmatia where the species was not reported so far (Figure 1). In addition, we found the species on the bank of Prokljan Lake west of Bićine (4350'8.10", $15^{\circ} 51^{\prime} 34.02^{\prime \prime}$, unmapped). The species was recently found also in salt marsh near Sečovlje, Slovenia (Stahrmüler 2001, Rottnesteiner 2014b) near the Slovenian-Croatian border.

According to published data, Samolus valerandi is occurred relatively frequently in Dalmatia (Mitić et al. 2009, Nikolić 2017), but it is quite rare in Istria (Stahrmüler 2001, Rottensteiner 2014a, Nikolić l. c.). This was confirmed by our survey as well.

Among rare species, Scorzonera parviflora needs special attention, since it is mentioned very seldom in the Croatian literature. It was published from Malo Blato on the island of Pag (Horvatić 1934; as S. candollei $=$ S. humilis). Mitić et al. (2009) report the species from other two sites on Pag (Vlašići, Kolansko blato). From this island it is recorded also by Magaš (2000), Alegro et al. (2010) and Dítě et al. (2015). Scorzonera parviflora is known from the brackish Vransko jezero as well (Sviličić 2013, Díte et al. 2015). We complete the chorological data of the species from the territory of Croatia, as those sites have not been published so far. The species indicates remarkable salt marsh habitats which are highly threatened by secondary succession associated with land use changes.

Another rare plant, Allium telmatum, was described a short time ago from the Dalmatian coast as endemic of the Quarner (Bogdanović et al. 2009). Certain locations with detailed coenological data (Malo blato, Kolansko blato) were published by Dítě et al. (2015). 
In the past, the majority of salt marshes were traditionally grazed or mowed. Extensive farming needs to be reintroduced in Croatia for conservation purposes (Stančić et al. 2008). Inidigenous plants growing in salt marshes are essential to the stability of the coast in trapping and binding sediments, they play an important role in the aquatic food web (Woodroffe 2002). These ecosystems are suffering an accelerating process of degradation due to land use changes and eutrophication (e.g. the Neretva River Delta). Numerous sites of drained or embanked salt marshes elsewhere, e.g. in Western Europe, are managed by grazing and their vegetation is relatively well-preserved (Jensen 1985, Bouchard et al. 2003, Loucougaray et al. 2004). Traditional farming (grazing, eventually mowing) is required in Jadrtovac, Ninsko blato, Rtina, Ljubač, Povljana, Vlašići, Malo Blato and Osor (Cres). Construction works e.g. in Lopar, Privlaka and Starigrad-Seline lead to irreversible devastation of salt marshes. Localities which still need protective measures by law are Zablaće-Mala Solina (Malo jezero), Brodarica, Privlaka, Solina (Krk), Rovinj and Cervar (Istria).

\section{Acknowledgements}

The study was supported by the Slovak Grant Agency for Science "VEGA" (grant No. 2/0001/16). We would like to thank Urban Šilc for providing valuable literature.

\section{References}

Adam, P. 1990: Saltmarsh Ecology. Cambridge University Press. New York, $456 \mathrm{pp}$.

Alegro, A., Bogdanović, S., Brana, S., Jasprica, N., Katalinić, A., Kovačić, S., Nikolić, T., Milović, M., Pandža, M. Posavec-Vukelić, V., Randić, M., Ruščić, M., Šegota, V., Šincek, D., Topić, J., Vrbek, M. \& Vuković, N. 2010: Botanički važna područja Hrvatske, Školska knjiga Zagreb, 529 pp.

Bogdanović, S., Brullo, S., Giusso del Galdo, G., Salmeri, C. 2009: A new autumn-flowering species of Allium (Alliaceae) from Croatia. Folia Geobotanica 44: 83-93.

Bouchard, V., Tessier, M., Digaire, R, Vivier, J. P., Valery, L., Gloaguen, J.C. \& Lefeuvre, J.C. 2003: Sheep grazing as management tool in western European saltmarshes. Comptes Rendus Biologies 326/ Suppl 1: 148-57.

Brandes, D. 2009: Autobahnen als Wuchsorte und Ausbreitungswege von Ruderal- und Adventivpflanzen. Braunschweiger Naturkundliche Schriften 8: 373-394.

Cori, B. 1999: Spatial dynamics of Mediterranean coastal regions. Journal of Coastal Conservation 5: 105-112.

Dítě, D. \& Dítětová, Z. 2016: Halophytes spreading along roadsides of northern Slovakia. Thaiszia-Journal of Botany 26(2): 165-172.
Dítě, D., Melečková, Z., Suvada, R., Píšs, V. \& Eliáš jun. P. 2015: The phytosociology and ecology of saline vegetation with Scorzonera parviflora in the Pannonian-Western Balkan gradient. Phytocenologia 45(1-2): 33-47.

EEA 2006: The changing faces of Europe's coastal areas, EEA report no. 6/2006, European Environment Agency, Copenhagen.

Eliáš, jun. P., Sopotlieva, D., Dítě, D., Hájková, P., Apostolova, I., Senko, D., Melečková, Z. \& Hájek, M. 2013: Vegetation diversity of salt-rich grasslands in the south-east Europe. Applied Vegetation Science 16(3): 521-537.

Euro+Med (2017): Euro+Med PlantBase - the information resource for Euro-Mediterranean plant diversity. Published on the Internet http:// ww2.bgbm.org/EuroPlusMed/ [accessed 22. 2. 2017].

Glasnović, P., Novak, Š., Behrič, S. \& Fujs, N. 2015: Towards a checklist of the vascular flora of the Neretva River Delta (Croatia). Natura Croatica 24(2): 163-190.

Horvatić, S. 1934: Flora i vegetacija otoka Paga. Prirodoslovna Istraživanja Kraljevine Jugoslavije 19: 116-372.

Jensen, A. 1985: The effect of cattle and sheep grazing on saltmarsh vegetation at Skallingen, Denmark. Vegetatio 60: 37-48.

Kamenjarin, J. \& Pavletic, Z. 2002: Vegetation of the Pantana area at Kaštela bay and its protections problem. Hacquetia 1(2): 185-192.

Király, G., Bidló, A., Takács, T., Eliáš, P. jr., Melečková, Z. \& Dítě, D. 2013: The occurrence of the littoral sedge species, Carex extensa (Cyperaceae) in the Pannonian Basin, Hungary. Biologia 68: 872-878.

Kutiel, P., Peled, Y. \& Geffen, E. 2000: The effect of removing scrub cover on annual plants and small mammals in a coastal sand dune ecosystem. Biology Conservation 94: 235-242.

Loucougaray, G., Bonis, A. \& Bouzille, J.B. 2004: Effects of grazing by horses and/or cattle on the diversity of coastal grasslands in western France. Biological Conservation 116: 59-71.

Magaš, D. 2000: Contribution to the knowledge of the geographical characteristics of the Pag island. Geoadria 5: 5-48.

Milović, M. 2002: The Flora of Šibenik and its surroundings. Natura Croatica 11(2): 171-223.

Mitić, B., Topić, J., Kovavić, S., Jasprica, N., Alegro, A., Milović, M., Dobrović, I., Rešetnik, I., Cigić, P., Ruščić, M., Bogdanović, S. \& Dolina, K. 2009: Kartiranje flore Dalmacije - Prioritetna područja: otok Pag, estuarij Krke, otok Vis i pučinski otoci, Pelješac i Mljet, otok Cetine [Mapping the flora of Dalmatia - Priority areas: Island of Pag, Vis, Mljet, Krka estuary, Pelješac and Cetine]. Sveučilište u Zagrebu, Prirodoslovno-matematički fakultet, Zagreb, 260 pp.

Milović, M. \& Pandža, M. 2010: A contribution to the vascular flora of the Šibenik Archipelago. Natura Croatica 19(1): 179-203.

Mucina, L., Bültmann, H., Dierßen, K., Theurillat, J.-P., Raus, T., Čarni, A., Šumberová, K., Willner, W., Dengler, J., [...] \& Tichý, L. 2016: Vegetation of Europe: Hierarchical floristic classification system of vascular plant, bryophyte, lichen, and algal communities. Applied Vegetation Science 19 (Suppl. 1): 3-264.

Nikolić, T. \& Topić, J. (eds.) 2005: Red Book of Vascular Flora of Croatia. Ministry of Culture, State Institute for Nature Protection, Republic of Croatia, Zagreb, 695 pp.

Nikolić, T (ed.) 2017: Flora Croatica. Retrieved February 09. 2017 from http://hirc. botanic.hr/fcd. 
Pandža, M. 1998: Flora of the islands of Krapanj and Prvić. Natura Croatica 7(4): 321-339.

Pandža, M., Franjić, J. \& Škvorc, Z. 2007: The salt marsh vegetation on the East Adriatic coast. Biologia 62: 24-13.

Rottensteiner, W. K. 2012: Vorarbeiten zu einer "Flora von Istrien", Teil XV. Carinthia II 202./122.: 601-662.

Rottensteiner, W. K. (ed.) 2014a: Exkursionsflora für Istrien. Naturwissenschaftlicher Verein für Kärnten, Klagenfurt, 1013 pp.

Rottensteiner, W. K. 2014b: Beiträge zur Flora von Istrien IV: Neue und seltene Taxa für Istrien, Kroatien und Slowenien. Fritschiana (Graz) 77: 1-61.

Šerá, B. 2008: Road vegetation in Central Europe - an example from the Czech Republic. Biologia 63: I08 I-I084.

Stahrmüler, W. 2001: Vorarbeiten zu einer „Flora von Istrien” Teil IV. Carinthia II 191/111: 409-457.

Stahrmüler, W. 2003: Vorarbeiten zu einer „Flora von Istrien” Teil VI. Carinthia II 193/113: 579-658.

Stahrmüler, W. 2007: Vorarbeiten zu einer „Flora von Istrien“ Teil X. Carinthia II 197/117: 407-496.

Stančić, Z., Brigić, A., Liber, Z., Rusak, G., Franjić, J. \& Škvorc, Ž 2008: Adriatic coastal plant taxa and communities of Croatia and their threat status. Acta Botanica Gallica 155: 179-199.

Sviličić, M. 2013: Analiza vegetacijskih promjena u parkovima prirode Telašćica i Vransko jezero [Analysis of vegetation changes in parks Nature Park Telašćica and Vranjsko Jazero]. Thesis. Sveučilište u

Zagrebu, Prirodoslovnomatematički fakultet, Zagreb, 40 pp.

Vladović, D., Gabelica, I., Piasevoli, G., Parmać, T., Matković, D. \& Županović, G. 2015: A contribution to the vascular flora of the Pantan territory (central Dalmatia, Croatia). Glasnik Hrvatskog botanickog društva 3(3): 18-26.

Woodroffe, C. D. 2002: Coasts: form, process and evolution. Cambridge University Press. New York, 640 pp.

\section{Appendix}

The list of localities and their short description (species we focused on are bolded):

1) Ston, south of the solana, $42^{\circ} 49^{\prime} 40.1^{\prime \prime}, 17^{\circ} 42^{\prime} 4.2^{\prime \prime}$. Remnants of salt marshes next to the abandoned solana, degraded, only slight occurrence of several coastal species, expansion of reed.

Carex divisa, Carex extensa, Halimione portulacoides, Juncus maritimus, Limonium narbonense, Sarcocornia fruticosa.

Date of visit: 30. 4. 2015

2) Blace, sandy beach $\mathbf{2} \mathrm{km}$ north-west from the village, belt of salt marshes in the Neretva River Delta, $43^{\circ} 0^{\prime} 57.58^{\prime \prime}, 17^{\circ} 28^{\prime} 3.422$.

Damaged by drainage and other human activities, several fragments of preserved vegetation. Carex extensa, Halimione portulacoides, Juncus maritimus, Limonium narbonense, Suaeda maritima, Tripolium pannonicum subsp. tripolium.

Date of visit: 30. 4. 2015

3) Trogir, Pantan reserve, saline marshland on the coast, $43^{\circ} 31$ '26.8", $16^{\circ} 16^{\prime} 17.6^{\prime \prime}$. Remnants of salt marshes attacked by human activities, massive expansion of reed, in the tidal zone small mosaics of indigenous halophytic vegetation dominated by Juncus maritimus.

Carex extensa, Juncus maritimus, Halimione portulacoides, Limonium narbonense.

Date of visit: 30. 4. 2015

4) Jadrtovac, river estuary, $43^{\circ} 40^{\prime} 52.0^{\prime \prime}, 1^{\circ} 57^{\prime} 28.7^{\prime \prime}$. Large coastal habitat with preserved halophytic vegetation.

Carex divisa, Halimione portulacoides, Juncus maritimus, Limonium narbonense, Sarcocornia fruticosa, Spergularia media.

Dates of visits: 26. 4. 2014, 17. 5. 2016

5) Brodarica, sea shore bay, $43^{\circ} 41^{\prime} 32.25^{\prime \prime}, 15^{\circ} 56^{\prime} 21.3^{\prime \prime}$. In the preserved halophytic vegetation dominate $\mathrm{Hal}$ imione portulacoides, Limonium narbonense, on the exposed surfaces Salicornia europaea agg. From the mainland it is filled up with garbage.

Artemisia caerulescens, Carex divisa, Halimione portulacoides, Juncus maritimus, Limonium narbonense, Salicornia europaea agg., Sarcocornia fruticosa, Spergularia media, Suaeda maritima.

Dates of visits: 1. 5. 2015

6) Zablaće, salt marshes of the hotel complex Solaris, on the banks of the channel St. Ante, 43 $3^{\circ} 2^{\prime} 3.9^{\prime \prime}$, $15^{\circ} 53^{\prime} \mathbf{2} .0^{\prime \prime}$. Large complex of salt marshes, partly affected by human activities (drainage, contamination from garbage) with well-developed halophytic vegetation. On the periodically dried surfaces dominate $A r$ throcnemum macrostachyum, away from the coastline are stands of Limonium narbonense and Juncus maritimus which requires more balanced water regime.

Arthrocnemum macrostachyum, Artemisia caerulescens, Carex divisa, Carex extensa, Halimione portulacoides, Juncus gerardii, Juncus maritimus, Limonium narbonense, Salsola soda, Sarcocornia fruticosa, Tripolium pannonicum subsp. tripolium.

Date of visit: 17. 5. 2016

7) Zablaće - bay, at the marina in the settlement, 43'2'13.9", 1552'16.9". Small preserved salt marsh with species-poor vegetation of Salicornion fruticosae. Halimione portulacoides, Juncus maritimus, Limonium narbonense, Sarcocornia fruticosa.

Date of visit: 17. 5. 2016 
8) Zablaće - Malo jazero (Mala Solina), northern shore of the pond, $43^{\circ} 42^{\prime} 51.2^{\prime \prime}, 15^{\circ} 51^{\prime} 53.2^{\prime \prime}$

Relatively well preserved, wide belt of coastal halophytic vegetation with Salicornion fruticosae is developed on the north and northwestern shores of the salt pond which is connected with the sea by a canal. Rich populations of Arthrocnemum macrostachyum and Triglochin barrelieri were there recorded.

Arthrocnemum macrostachyum, Halimione portulacoides, Juncus maritimus, Limonium narbonense, Limonium virgatum, Parapholis incurva, Salsola soda, Sarcocornia fruticosa, Triglochin barrelieri.

Date of visit: 17. 5. 2016

9) Zablaće - salt pond north of Velo Blato, $43^{\circ} 43^{\prime}$ 02.8", 15'52'16.7"

Relatively well preserved site with a small periodic salt pond without a visible connection with the sea. Artemisia caerulescens, Juncus maritimus, Limonium narbonense, Puccinellia festuciformis, Salicornia europea agg., Salsola soda, Sarcocornia fruticosa, Triglochin barrelieri.

Date of visit: 26.4 .2014

10) Ivinj, $43^{\circ} 47^{\prime} 50.1 ", 15^{\circ} 40^{\prime} 51.3 "$

Small preserved stands of Salicornion fruticosae in the bay of the stream estuary.
Artemisia caerulescens, Carex extensa, Halimione portulacoides, Juncus gerardii, Juncus maritimus, Limonium narbonense, Sarcocornia fruticosa.

Dates of visits: 1. 5. 2015, 17. 5. 2016

11) Vransko jazero, north shores of the lake, $43^{\circ} 56^{\prime}$ 3.4", $15^{\circ} 30^{\prime} 45.8^{\prime \prime}$

Moderately saline marshes not connected with the sea, typical coastal wetland species of the class Sarcoccornietea fruticosae are absent. Attempts of drainage, large areas are expanded by reed and Cladium mariscus. On the shallow lakeshore Schoenoplectus litoralis is abundant.

Eleocharis uniglumis, Juncus gerardii, Juncus maritimus, Samolus valerandii, Scorzonera parviflora, Tripolium pannonicum subsp. tripolium.

Dates of visits: 30. 4. 2011, 27. 4. 2012, 1. 5. 2015, 24. 8. 2015, 17. 5. 2016

12) Karin Gornji, mouth of the river Karišnica, $44^{\circ} 7^{\prime}$ 49.3", 15³7'7.9" (Figure 2)

Large complex of salt marshes with preserved vegetation. Stands of Juncus maritimus and Limonium narbonense dominates, on the exposed bottoms primarily affected by tidal water are wide belts of Salicornia europaea agg.

Artemisia caerulescens, Carex extensa, Centaurium

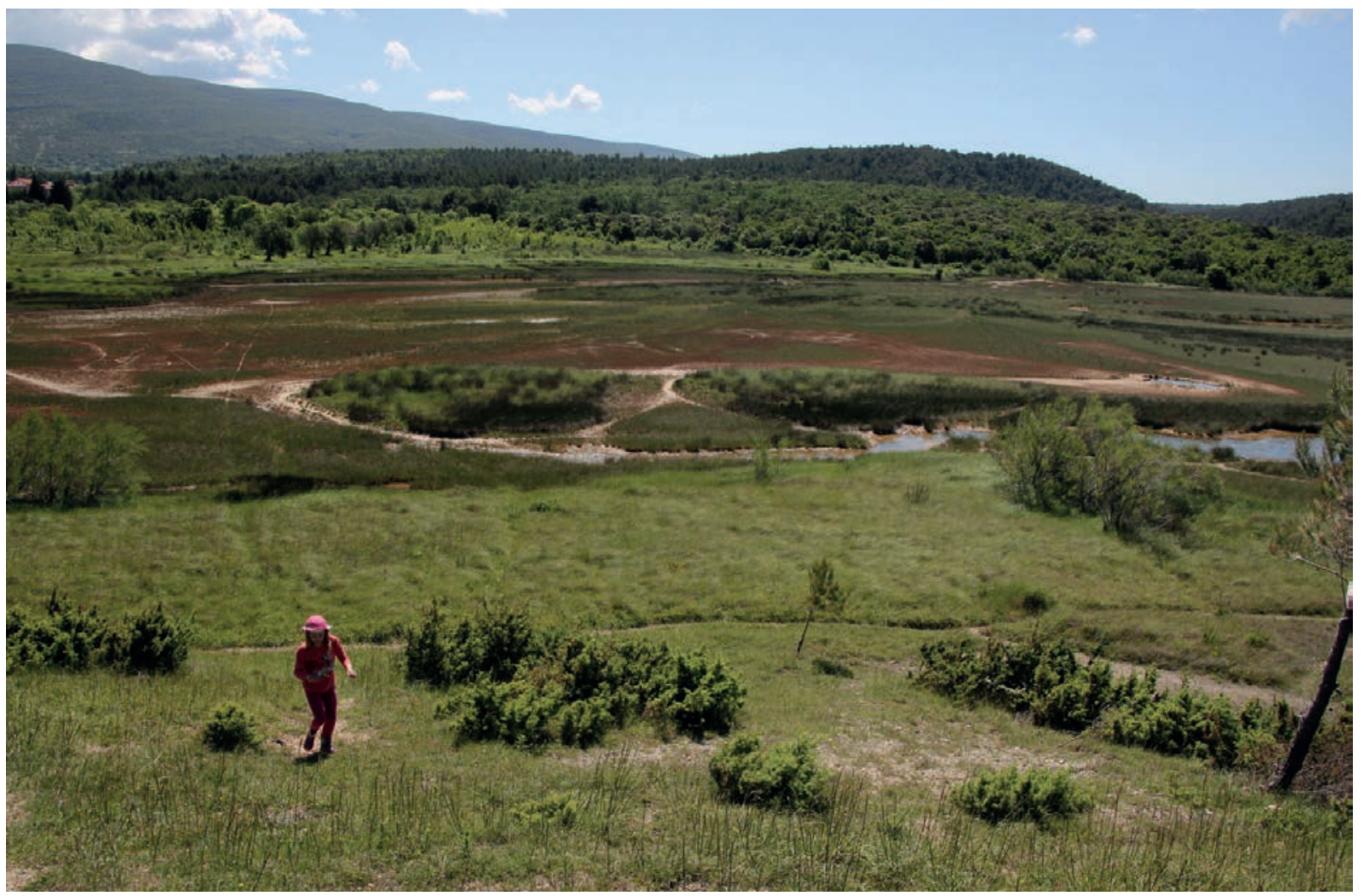

Figure 2: Salt marshes in the estuary of the Karišnica River (Karin Gornji).

Slika 2: Slana mokrišča v estuariju reke Karišnice (Karin Gornji). 
spicatum, Juncus maritimus, Limonium narbonense, Salicornia europea agg., Spergularia salina, Tripolium pannonicum subsp. tripolium.

Date of visit: 18. 5. 2016

13) Karin Gornji, northen part of the settlement, $44^{\circ}$ $8^{\prime} 19.3^{\prime \prime}, 15^{\circ} 37^{\prime} 48.5^{\prime \prime}$

In the bay several species of the alliance Salicornion fruticosae form a narrow belt of preserved vegetation, rich populations of Juncus maritimus as well.

Artemisia caerulescens, Halimione portulacoides, Juncus maritimus, Limonium narbonense, Salicornia europaea agg., Tripolium pannonicum subsp. tripolium.

Date of visit: 18. 5. 2016

14) Vrulje, small salt marsh in the settlement, $44^{\circ} 8$ 38.6", 1537'54.4"

Well-developed vegetation of Salicornion fruticosae, rich populations of Carex extensa, smaller patches of Salicornia europaea agg. and Suaeda maritima.

Artemisia caerulescens, Carex extensa, Halimione portulacoides, Juncus gerardii, Juncus maritimus, Limonium narbonense, Salicornia europaea agg., Samolus valerandii, Suaeda maritima, Tripolium pannonicum subsp. tripolium.

Date of visit: 17. 5. 2016
15) Posedarje, bay with a chapel Svati Duh, $44^{\circ} 12$ 20.9", 15²8'15.6"

This large coastal wetland is considerably expanded by reed. Vast accumulation of organic material from the sea (algae) is also notable. In stands not affected by reed expansion dominate Juncus maritimus, Limonium narbonense and Aster tripolium subsp. tripolium. Artemisia caerulescens, Halimione portulacoides, Juncus maritimus, Limonium narbonense, Salsola soda, Salicornia europaea agg., Tripolium pannonicum subsp. tripolium.

Dates of visits: 3. 5. 2015, 24. 8. 2015, 18. 5. 2016

16) Nin, Ninska solana, $44^{\circ} 14^{\prime} 15.3^{\prime \prime}, 1^{\circ} 11^{\prime} 9.5^{\prime \prime}$ (Fig. 3) In the salt evaporation basins grow species of the alliance Salicornion fruticosae, on the western part of the site well-developed stands of Juncion maritimi.

Carex divisa, Carex extensa, Halimione portulacoides, Juncus maritimus, Limonium narbonense, Plantago cornuti, Salicornia europaea agg., Sarcocornia fruticosa, Scorzonera parviflora, Suaeda maritima. Date of visit: 27. 4. 2014

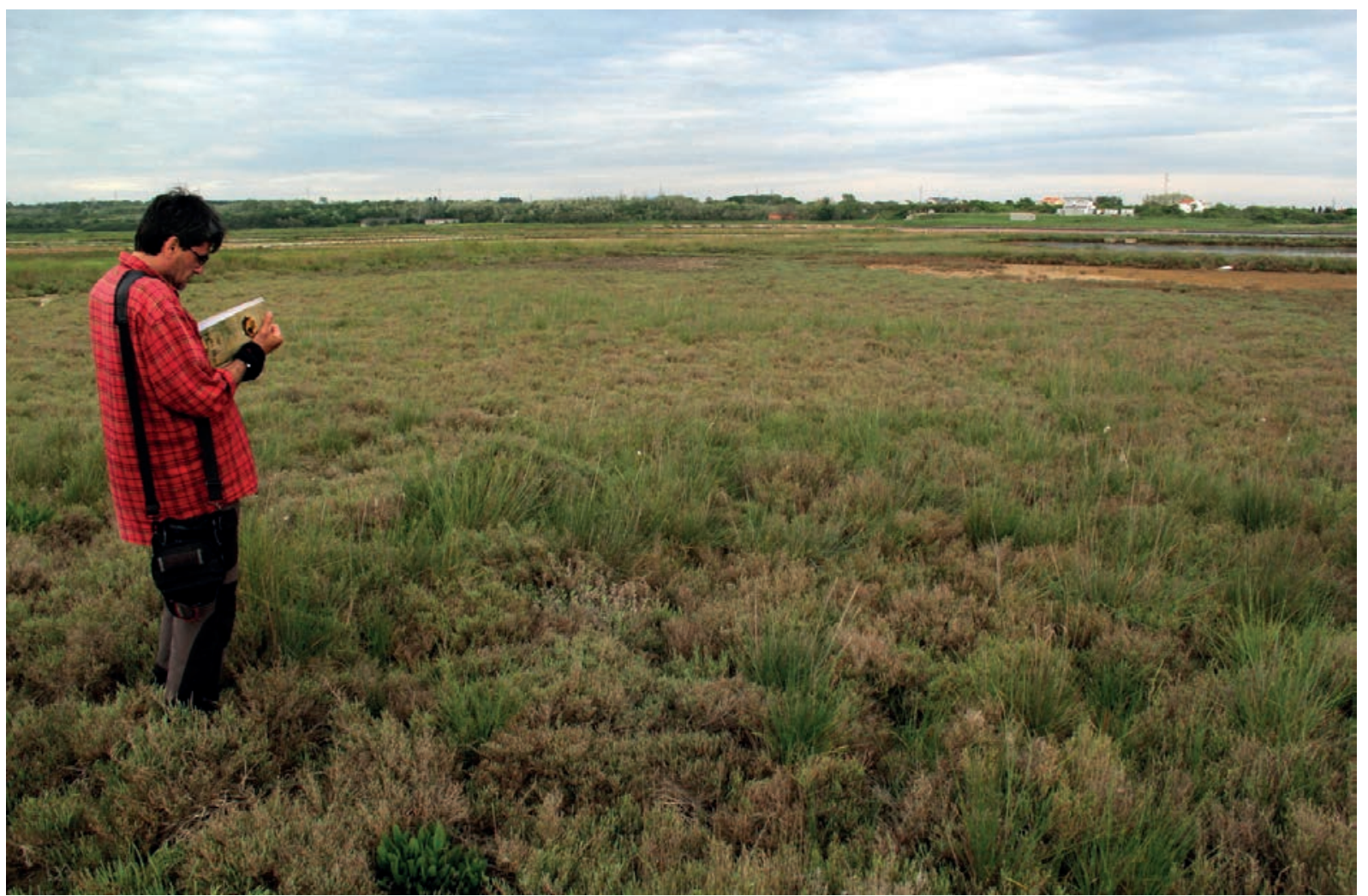

Figure 3: Salt marshes in the abandoned salt works of the Ninska solana. Slika 3: Slana mokrišča na opuščenih solinah v Ninski solani. 


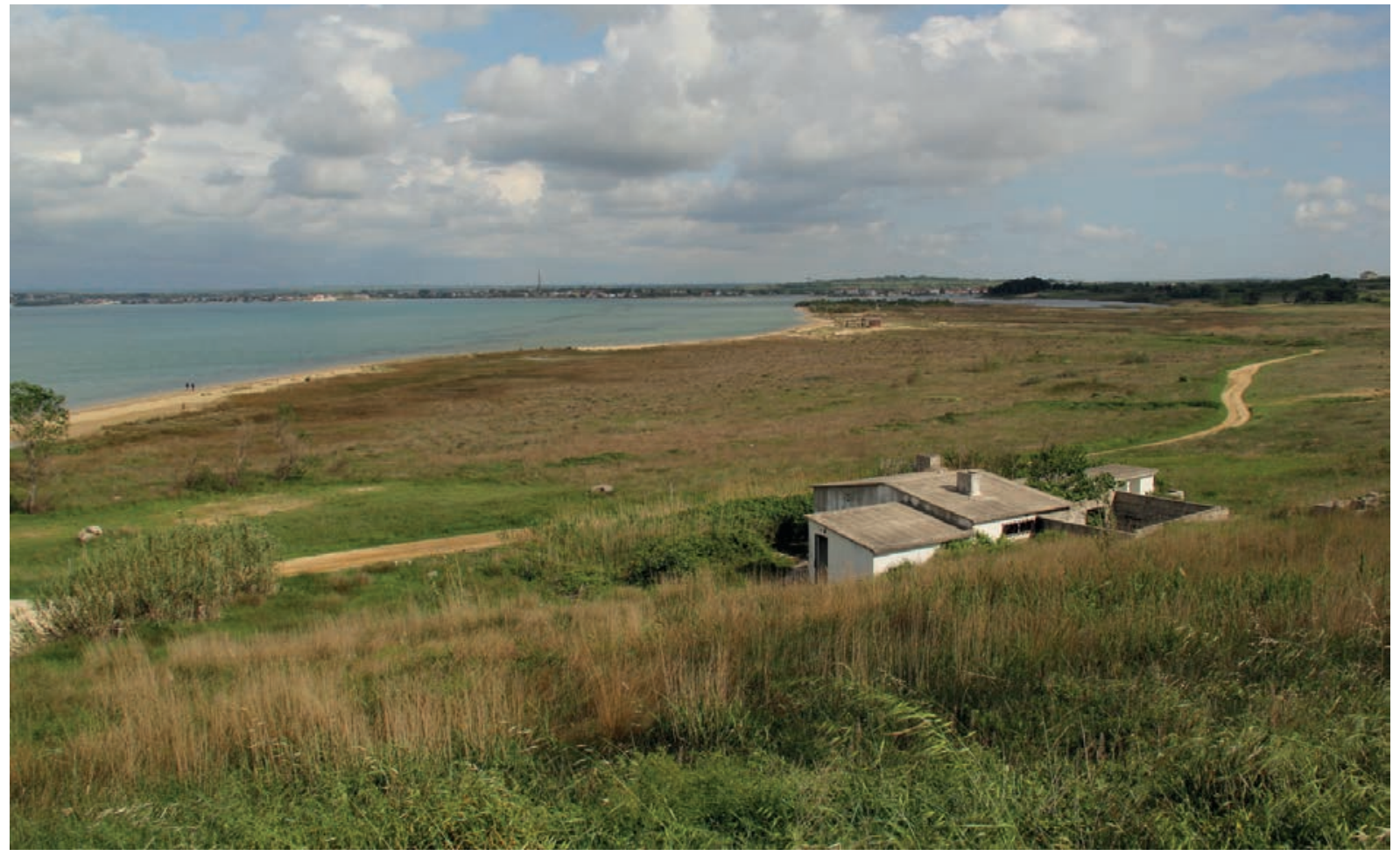

Figure 4: Ninsko blato - a remarkable site of salt marsh vegetation of the Dalmatian coast.

Slika 4: Ninsko blato - pomembno rastišče slane močvirske vegetacije na dalmatinski obali.

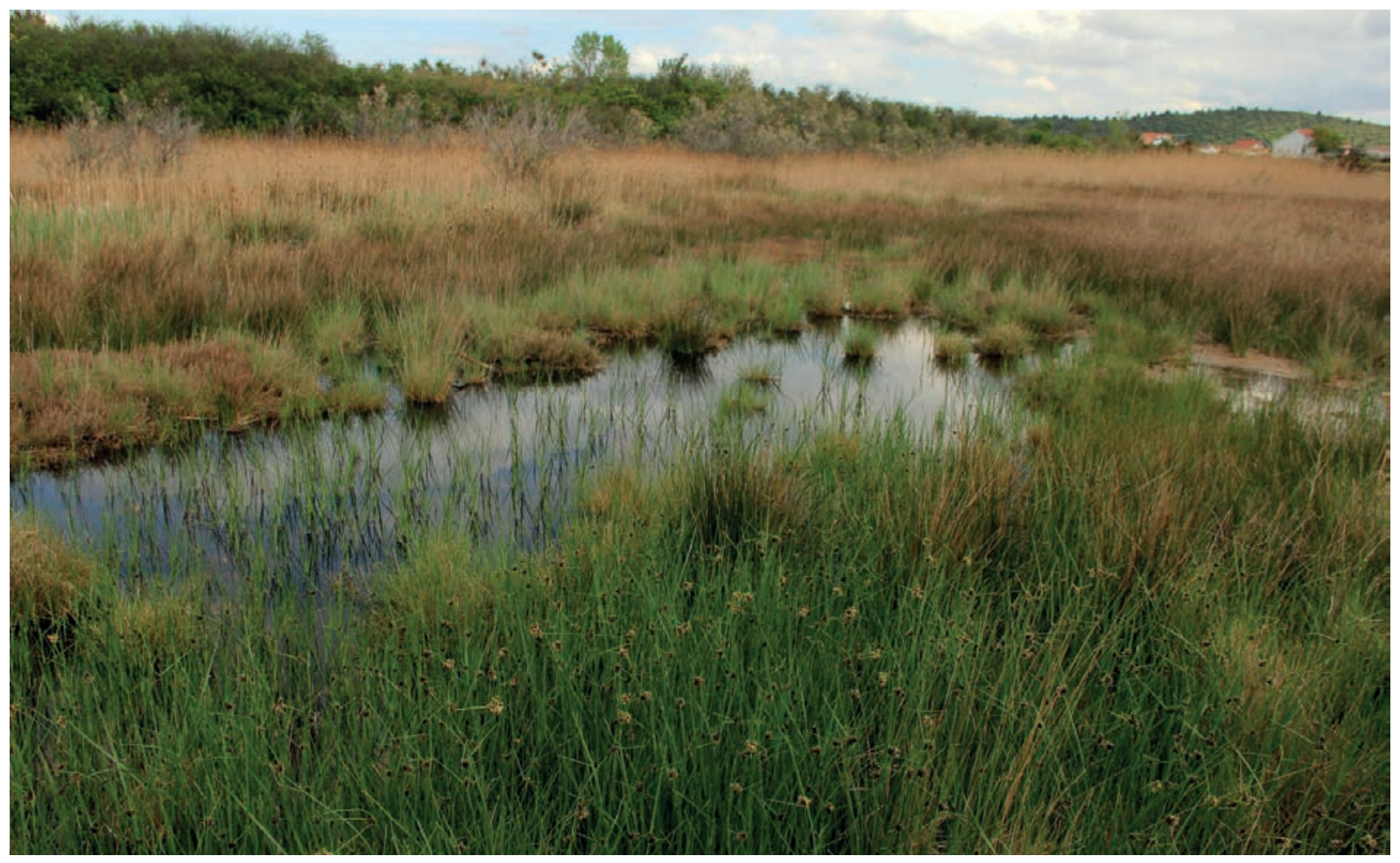

Figure 5: Ljubač - a remarkable site of salt marsh vegetation of the Dalmatian coast.

Slika 5: Ljubač - pomembno rastišče slane močvirske vegetacije na dalmatinski obali. 
17) Ninsko blato, $44^{\circ} 15^{\prime} 8.4^{\prime \prime}, 1^{\circ} 10^{\prime} 10.7^{\prime \prime}$ (Figure 4) Large, botanically remarkable site of salt marshes situated directly on the sandy beach visited by masses of tourists. The majority of the site is occupied by stands of Juncus maritimus.

Allium telmatum, Artemisia caerulescens, Carex divisa, Carex extensa, Halimione portulacoides, Juncus maritimus, Limonium narbonense, Plantago cornuti, Scorzonera parviflora, Sarcocornia fruticosa, Triglochin barrelieri, Triglochin maritima.

Dates of visits: 28. 4. 2014, 22. 8. 2015

18) Ljubač, large salt marsh in the bay, $44^{\circ} 15^{\prime} 15.1^{\prime \prime}$, 15¹8'2.5" (Figure 5)

According to our knowledge this site is the most remarkable among the visited salt marshes of the Croatian coast; the highest number of halophytes and the larges variety of vegetation types were recorded here. The site is threatened by emerging tourism, it would be appropriate to ensure protection. It is the northernmost locality where we recorded Arthrocnemum macrostachyum. Arthrocnemum macrostachyum, Artemisia caerulescens, Carex divisa, Carex extensa, Eleocharis uniglumis, Halimione portulacoides, Juncus gerardii, Juncus maritimus, Limonium narbonense, Limonium bellidifolium, Limonium virgatum, Parapholis incurva, Plantago cornuti, Samolus valerandii, Salicornia europaea agg., Sarcocornia fruticosa, Scorzonera parviflora, Triglochin barrelieri, Tripolium pannonicum subsp. tripolium.

Dates of visits: 2. 5. 2015, 22. 8. 2015, 18. 5. 2016

19) Modrić, $44^{\circ} 15^{\prime} 30.4^{\prime \prime}, 15^{\circ} 32^{\prime} 26.2^{\prime \prime}$

Salt marsh at the estuary of the creek with narrow inlets, several freshwater springs mouthing to the sea. Very rich populations of Carex extensa, typical species of the Salicornion fruticosae are absent.

Juncus gerardii, Juncus maritimus, Limonium narbonense, Samolus valerandi, Tripolium pannonicum subsp. tripolium.

Date of visit: 3. 5. 2015

20) Privlaka, Virski most, $44^{\circ} 16^{\prime} 32.2^{\prime \prime}, 1^{\circ} 07^{\prime} 4.1^{\prime \prime}$

Relatively large salt marsh in the bay, Salicornion fruticosae species dominate. Recently it is increasingly damaged by road construction and parcel developments.

Artemisia caerulescens, Carex extensa, Centaurium spicatum, Halimione portulacoides, Juncus maritimus, Limonium narbonense, Limonium virgatum, Parapholis incurva, Salicornia europea agg., Sarcocornia fruticosa, Suaeda maritima, Triglochin barrelieri.

Dates of visits: 27. 4. 2014, 28. 7. 2016

21) Rtina, salt marshes in the river estuary, $44^{\circ} 16^{\prime} 49.7^{\prime \prime}$, 15¹8'21.6" (Figure 6)

Together with Ljubač it is the most remarkable site

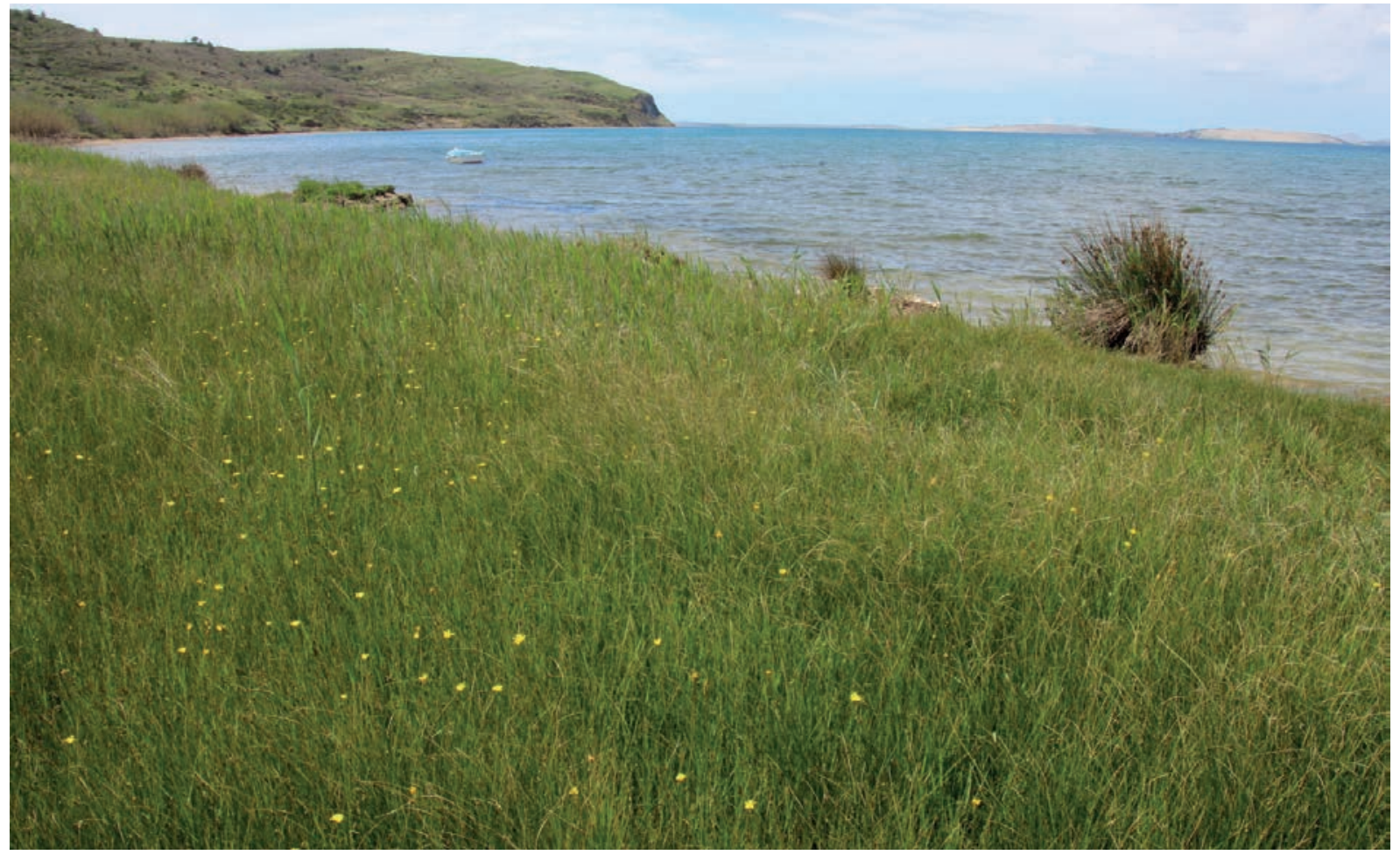

Figure 6: Rtina - a remarkable site of salt marsh vegetation of the Dalmatian coast. Rich stands of Scorzonera parviflora. Slika 6: Rtina - pomembno rastišče slane močvirske vegetacije na dalmatinski obali. Bogati sestoji vrste Scorzonera parviflora. 
of coastal halophytic habitats in Croatia. Beyond salt marshes far from the coastline where tidal waters do not reach wet meadows are developed with thousands specimens of Orchis laxiflora and Chouardia litardierei. Human intervention on this site is also reflected, one part was drained due to the landing area for paragliding.

Artemisia caerulescens, Carex divisa, Carex extensa, Eleocharis uniglumis, Halimione portulacoides, Juncus gerardii, Juncus maritimus, Limonium narbonense, Parapholis incurva, Parapholis filiformis, Sarcocornia fruticosa, Scorzonera parviflora, Triglochin barrelieri, Tripolium pannonicum subsp. tripolium. Dates of visits: 29. 4. 2014, 18. 5. 2016

22) Starigrad, Seline, $44^{\circ} 16^{\prime} 59.4^{\prime \prime}, 15^{\circ} 27^{\prime} 41.1^{\prime \prime}$

Small salt marsh vanishing due to construction works. Remnant vegetation with Juncus maritimus and Limonium narbonense.

Artemisia caerulescens, Carex extensa, Juncus maritimus, Limonium narbonense.

Date of visit: 3. 5. 2015

23) Pag, Vlašići, $44^{\circ} 19^{\prime} 15.0^{\prime \prime}, 1^{\circ} 12^{\prime} 25.3 "$ (Figure 7)

The site is featured by well developed stands of Salicornion fruticosae and Juncion maritimi. Rich populations of several rare coastal salt marsh species.
Allium telmatum, Artemisia caerulescens, Carex divisa, Carex extensa, Eleocharis uniglumis, Halimione portulacoides, Juncus gerardii, Juncus maritimus, Limonium narbonense, Parapholis filiformis, Salsola soda, Sarcocornia fruticosa, Scorzonera parviflora, Suaeda maritima, Triglochin barrelieri. Dates of visits: 26. 8. 2011, 28. 4. 2012, 23. 8. 2015, 18. 5.2016

24) Pag, Povljana, salt marsh in the Stara Povljana gulf, $44^{\circ} 19^{\prime} 46.4 ", 15^{\circ} 7^{\prime} 53.7^{\prime \prime}$

Relatively unharmed salt marsh in the sandy bay is surrounded by agricultural land. Expansion of Phragmites australis.

Carex divisa, Eleocharis uniglumis, Juncus gerardii, Juncus maritimus, Plantago cornuti, Scorzonera parviflora, Tripolium pannonicum subsp. tripolium.

Date of visit: 29. 4. 2014

25) Pag, Povljana, north of the settlement, $44^{\circ} 21^{\prime} 16.4^{\prime \prime}$, $15^{\circ} 5^{\prime} 47.1 "$

Small salt marsh on the shore of the lagoon connected with the sea by channel.

Carex extensa, Juncus maritimus, Limonium narbonense.

Date of visit: 18. 5. 2016

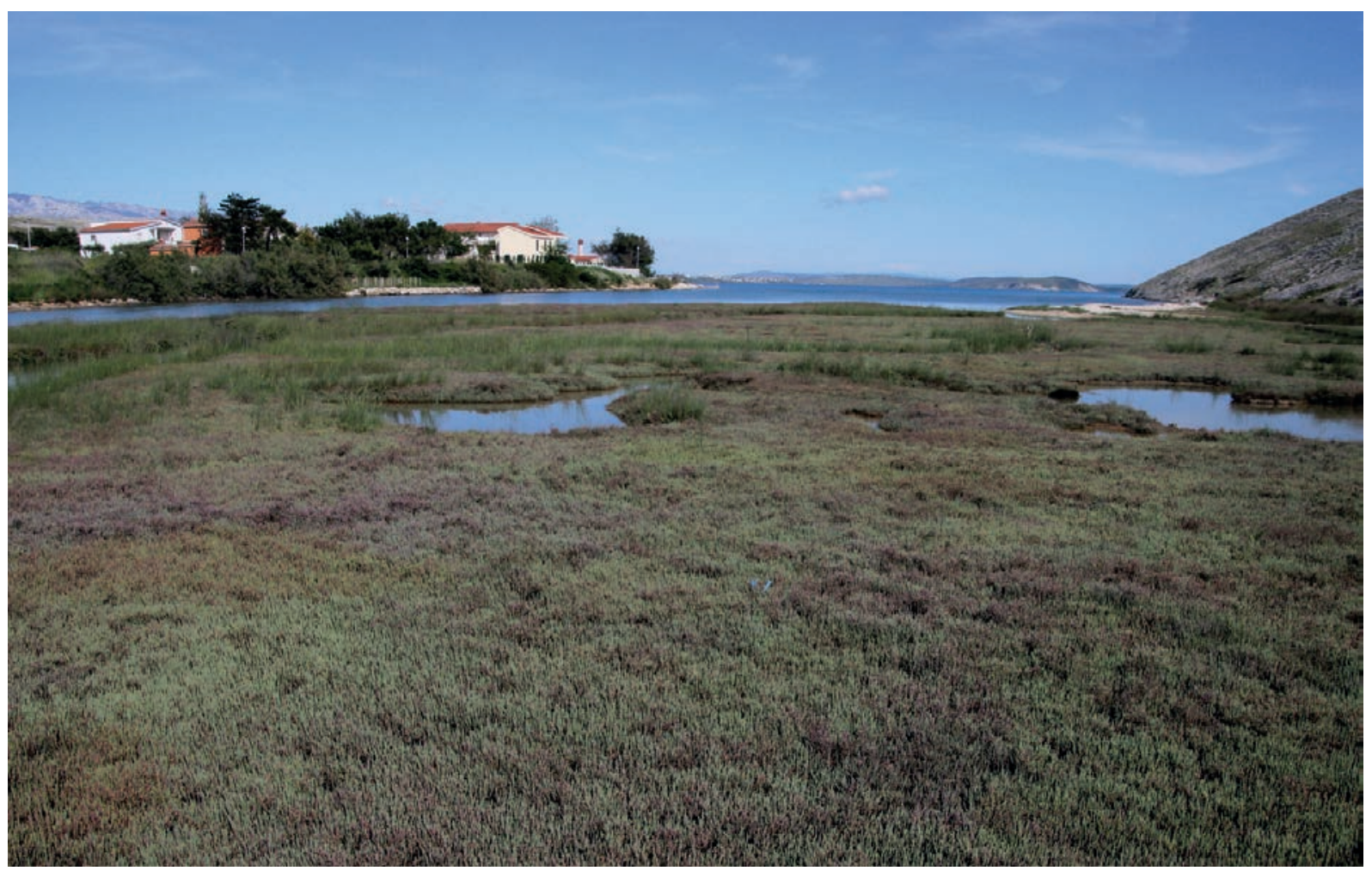

Figure 7: Vlašići - a remarkable site of salt marsh vegetation of the Dalmatian coast (Pag Island) Slika 7: Vlašići - pomembno rastišče slane močvirske vegetacije na dalmatinski obali (otok Pag). 
26) Pag, solana Dinjiška, $44^{\circ} 21^{\prime} 36.8^{\prime \prime}, 15^{\circ} 10^{\prime} 45.6^{\prime \prime}$ Salt evaporation ponds, lagoons and salt meadows. Allium telmatum, Artemisia caerulescens, Carex extensa, Carex divisa, Halimione portulacoides, Juncus gerardii, Juncus maritimus, Limonium narbonense, Samolus valerandii, Salicornia europaea agg., Sarcocornia fruticosa.

Dates of visits: 28. 8. 2011, 20. 8. 2015

27) Pag, Malo Blato, $44^{\circ} 22^{\prime} 4.8^{\prime \prime}, 1^{\circ} 7^{\prime} 1.3^{\prime \prime}$

This well-known site is recently overgrown by Cladium mariscus. Salt marshes of the alliance Juncion maritimi are preserved in the northwestern part.

Allium telmatum, Carex extensa, Juncus gerardii, Juncus maritimus, Samolus valerandii, Scorzonera parviflora.

Dates of visits: 31. 8. 2011, 30. 4. 2012, 29. 4. 2014, 18. 5.2016

28) Pag, Paška solana, $44^{\circ} 25^{\prime} 2.5^{\prime \prime}, 15^{\circ} 4^{\prime} 44.5^{\prime \prime}$

Vast majority of the site are the salt evaporation ponds. On the western border of the site are logoons with vegetation of Salicornion fruticosae, sporadically occur stands of Juncion maritimi.

Allium telmatum, Artemisia caerulescens, Carex extensa, Carex divisa, Halimione portulacoides, Juncus gerardii, Juncus maritimus, Limonium narbonense, Samolus valerandii, Salicornia europaea agg., Sarcocornia fruticosa, Scorzonera parviflora, Suaeda maritime, Tripolium pannonicum subsp. tripolium.

Dates of visits: 28. 8. 2011, 30. 4. 2012, 29. 4. 2014, 20. 8. 2015, 18. 5. 2016

29) Pag, Metajna, salt marsh on a slope with no connection with the sea, $44^{\circ} 30^{\prime} 10.9^{\prime \prime}, 15^{\circ} 1^{\prime} 15.0^{\prime \prime}$

Peculiar site, the marshes are watered by springs emerging from the moderate slopes $15 \mathrm{~m}$ above the sea level. It is threatened by construction of a large parking area.

Allium telmatum, Eleocharis uniglumis, Juncus maritimus, Samolus valerandii, Scorzonera parviflora.

Dates of visits: 23. 8. 2015, 19. 5. 2016

30) Pag, Kolansko blato, ornithological reserve, $44^{\circ}$ 30'51.8", 14'55'6.9"

Large site on the shores of the lagoon with vegetation of Salicornion fruticosae, further away from the sea are stands of Juncion maritimi. To these marshes are connected wet meadows with thousands of $\mathrm{Or}$ chis laxiflora and Chouardia litardierei. The majority of the site is however damaged by drainage and expanded by reed.

Allium telmatum, Artemisia caerulescens, Carex extensa, Carex divisa, Halimione portulacoides, Juncus maritimus, Limonium narbonense, Samolus valeran- dii, Sarcocornia fruticosa, Scorzonera parviflora, Tripolium pannonicum subsp. tripolium.

Dates of visits: 1. 5. 2011, 30. 8. 2011, 29. 4. 2012

31) Cres, salt marsh in the lagoon near Osor, $44^{\circ} 41^{\prime}$ 38.1", $14^{\circ} 23^{\prime} 50.7^{\prime \prime}$

Large salt marsh with well developed vegetation of Salicornion fruticosae. One of the few managed sites, grazed by sheep.

Artemisia caerulescens, Halimione portulacoides, Juncus gerardii, Juncus maritimus, Limonium narbonense, Salicornia europea agg., Sarcocornia fruticosa.

Date of visit: 20. 5. 2016

32) Rab, Kampor, salt marsh in the bay, $44^{\circ} 46^{\prime} 4.2^{\prime \prime}$, $14^{\circ} 44^{\prime} 33.4 "$

Small salt marsh with well developed stands of Salicornion fruticosae.

Carex extensa, Halimione portulacoides, Juncus maritimus, Limonium narbonense, Sarcocornia fruticosa, Tripolium pannonicum subsp. tripolium.

Date of visit: 19. 5. 2016

33) Rab, Supetarska Draga, $44^{\circ} 47^{\prime} 55.2^{\prime \prime}, 1^{\circ} 43^{\prime} 40.9^{\prime \prime}$ Large salt marsh in the river estuary. Species of the alliance Salicornion fruticoase prevail, vast areas are highly salinized without vegetation cover.

Artemisia caerulescens, Carex extensa, Carex divisa, Halimione portulacoides, Juncus maritimus, Limonium narbonense, Salicornia europaea agg., Sarcocornia fruticosa, Tripolium pannonicum subsp. tripolium. Dates of visits: 20. 7. 2010, 2. 5. 2011, 19. 5. 2016

34) Rab, Lopar, near the marina, $44^{\circ} 50^{\prime} 9.4^{\prime \prime}, 1^{\circ} 43^{\prime} 30.2^{\prime \prime}$ Remnants of coastal vegetation damaged by construction.

Carex extensa, Centaurium spicatum, Halimione portulacoides, Juncus maritimus, Limonium narbonense, Salicornia europea agg., Sarcocornia fruticosa, Spergularia media, Suaeda maritima.

Dates of visits: 19. 7. 2010, 19. 5. 2016

35) Cres, near the marina in the town Cres, $44^{\circ} 56^{\prime} 39.2^{\prime \prime}$, $14^{\circ} 24^{\prime} 54.6 "$

Small degraded salt marsh partially expanded by reed. Carex extensa, Juncus maritimus, Limonium narbonense.

Date of visit: 20. 5. 2016

36) Rovinj-Val Saline camping, bay north of the town, $45^{\circ} 6^{\prime} 56.3^{\prime \prime}, 13^{\circ} 37^{\prime} 26.7^{\prime \prime}$

The largest preserved salt marsh on Istria with well developed vegetation of the alliance Salicornion fruticosae.

Artemisia caerulescens, Halimione portulacoides, Juncus maritimus, Limonium narbonense, Sarcocornia fruticosa, Suaeda maritima.

Date of visit: 20. 5. 2016 
37) Krk, Soline, salt marsh in the bay, $45^{\circ} 8^{\prime} 57.6^{\prime \prime}$, $14^{\circ} 36^{\prime} 9.3^{\prime \prime}$

Large salt marshes where typical species of Salicornion fruticosae prevail. The site is endangered by massive tourism (beach, healing mud).

Artemisia caerulescens, Carex extensa, Juncus gerardii, Juncus maritimus, Limonium narbonense, Sarcocornia fruticosa, Tripolium pannonicum subsp. tripolium. Date of visit: 19. 5. 2016

\section{8) Funtana, $45^{\circ} 10^{\prime} 44.2^{\prime \prime}, 13^{\circ} 36^{\prime} 17.7^{\prime \prime}$}

Degraded salt marsh overgrown by reed. Remnants are of the species of the alliance Salicornion fruticosae. Artemisia caerulescens, Halimione portulacoides, Juncus maritimus, Limonium narbonense, Sarcocornia fruticosa, Suaeda maritime, Tripolium pannonicum subsp. tripolium.

Date of visit: 20. 5. 2016

39) Cervar, $45^{\circ} 16^{\prime} 35.9^{\prime \prime}, 1^{\circ} 36^{\prime} 18.6^{\prime \prime}$

Small salt marsh in the bay, well developed, speciespoor stands of Salicornion fruticosae.

Artemisia caerulescens, Halimione portulacoides, Juncus maritimus, Limonium narbonense, Salicornia europea agg., Sarcocornia fruticosa, Suaeda maritima.

Date of visit: 21. 5. 2016
40) Vabriga, Santa Marina, $45^{\circ} 17^{\prime} 8.8^{\prime \prime}, 13^{\circ} 36^{\prime} 10.7^{\prime \prime}$ (Figure 8)

Small salt marsh in the bay, well developed, speciespoor stands of Salicornion fruticosae.

Artemisia caerulescens, Halimione portulacoides, Juncus maritimus, Limonium narbonense, Sarcocornia fruticosa, Suaeda maritima.

Dates of visits: 21. 5. 2016

41) Lanterna, $45^{\circ} 18^{\prime} 51.44^{\prime \prime}, 13^{\circ} 36^{\prime} 53.0^{\prime \prime}$

Small degraded saline vegetation cut off the sea by the road.

Juncus gerardii, Juncus maritimus, Limonium narbonense, Salicornia europaea agg., Sarcocornia fruticosa, Triglochin maritima.

Dates of visits: 30. 8. 2005, 21. 5. 2016

42) Antenal, lagoon in the Mirna river estuary, $45^{\circ} 19^{\prime}$ 11.9", 13³6'3.5"

Peculiar site with large salt marshes in the river mouth, initial, species-poor vegetation, part are overgrown by Phragmites australis.

Juncus maritimus, Limonium narbonense, Triglochin maritima.

Dates of visits: 30. 8. 2005, 21. 5. 2016

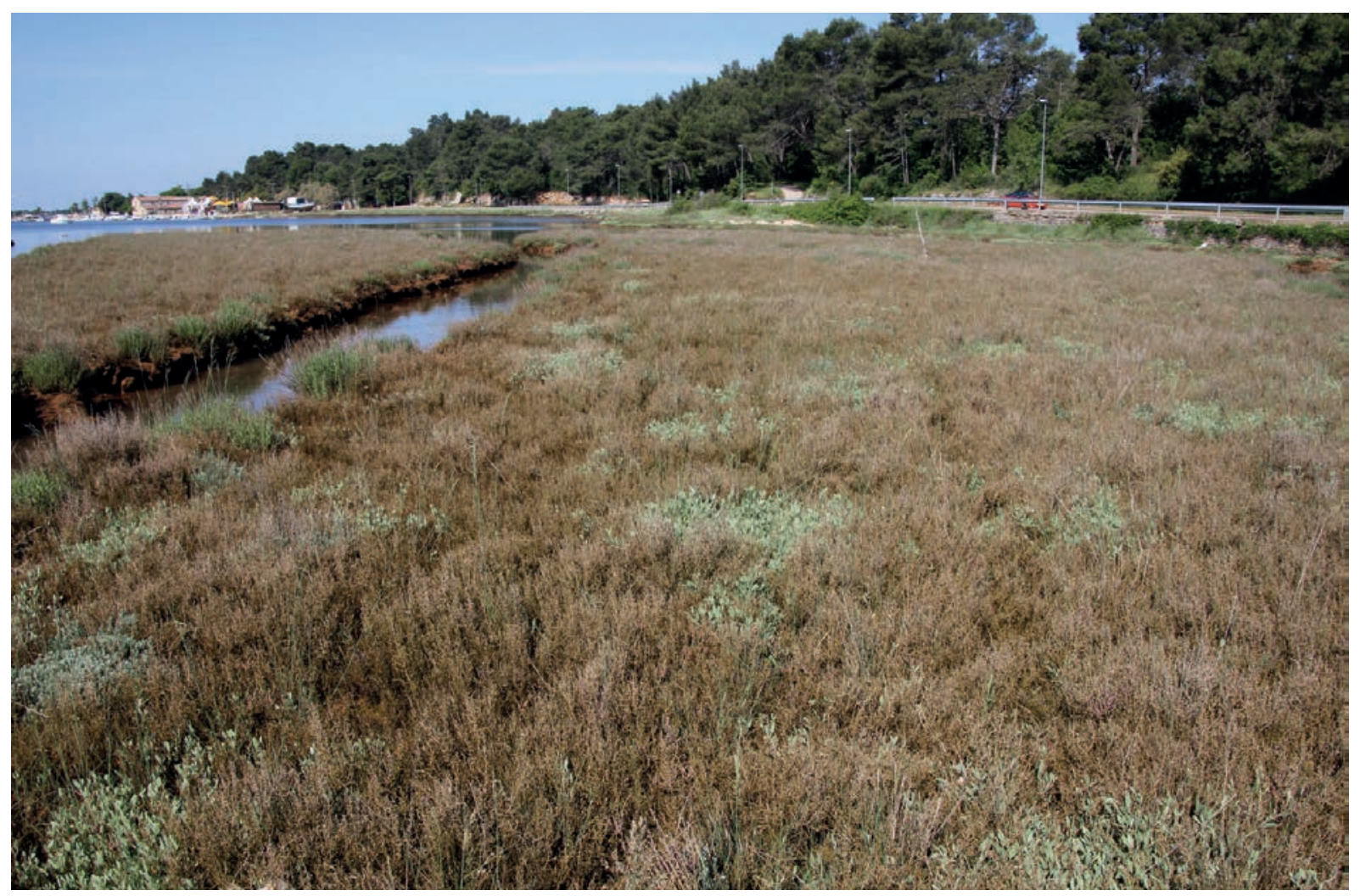

Figure 8: Salt marshes at Vabriga, Santa Marina (Istria).

Slika 8: Slana močvirja pri Vabrigi, Santa Marina (Istra). 